\title{
Analisa SWOT dan STP (Segmentasi, Tertarget, Posisi) terhadap Strategi Pemasaran Digital pada Usaha Mikro - Bunda Culinary
}

\author{
SWOT and STP (Segmentation, Targeting, Positioning) \\ Analysis in Digital Marketing Strategies for \\ Micro Businesses - Bunda Culinary
}

\author{
Henky Hendrawan ${ }^{1}$ \\ 1)Program Studi Ilmu Administrasi, Sekolah Tinggi Ilmu Administrasi Menarasiswa, Bogor, Indonesia \\ *Corresponding Email: hendrawan16@gmail.com
}

\begin{abstract}
Abstrak
Perubahan pemasaran konvensional menjadi pemasaran digital membawa dampak pada dunia usaha, tak terkecuali usaha mikro. Sehingga diperlukan strategi tertentu dalam menghadapi pemasaran digital. Analisa SWOT dan analisa STP diantara beberapa analisa lainnya yang dapat digunakan untuk menentukan strategi pemasaran. Tujuan dari penelitian ini adalah untuk mencari gambaran tentang penggunaan analisa SWOT dan analisa STP yang diimplementasikan pada usaha mikro yakni 'Bunda Culinary'. Analisa SWOT dan Analisa STP digunakan dalam rangka untuk melihat strategi pemasaran digital apa yang ditempuh oleh pelaku usaha mikro 'Bunda Culinary'. Metode penelitian yang digunakan bersifat survei deskriptif. Teknik pengumpulan data dalam penelitian ini adalah observasi dan wawancara. Adapun hasil yang didapat adalah strategi untuk pemasaran digital yang dilakukan baru pada pola Pemasaran Relasi, Pemasaran Mulut ke mulut, Pemasaran Musiman, dan Pemasaran Media Sosial. Sementara untuk pengembangan ke arah Pemasaran B2B dan Pemasaran B2C belum tergarap. Dan juga belum adanya personal atau tim tertentu yang menangani Pemasaran digital.

Kata Kunci: Analisa SWOT, Analisa STP, Strategi Pemasaran Digital, Usaha Mikro.
\end{abstract}

\begin{abstract}
The change of conventional marketing to digital marketing has an impact on the business world, including micro businesses. So that a certain strategy is needed in dealing with digital marketing. SWOT analysis and STP analysis among several other analyzes that can be used to determine a marketing strategy. The purpose of this study is to find an overview of the use of SWOT analysis and STP analysis implemented in micro enterprises, namely 'Bunda Culinary'. SWOT analysis and STP analysis are used in order to see what digital marketing strategies are being pursued by the micro entrepreneur 'Bunda Culinary'. The research method used is a descriptive survey. Data collection techniques in this study were observation and interviews. The results obtained are strategies for digital marketing that are carried out only on the pattern of Relationship Marketing, Word of mouth Marketing, Seasonal Marketing, and Social Media Marketing. Meanwhile, the development towards B2B Marketing and B2C Marketing has not been carried out. And there is also no specific personal or team handling digital marketing. Keywords: SWOT Analyst, STP Analyst, Digital Marketing Strategy, Micro-Business.
\end{abstract}

How to Cite: Hendrawan, H. (2021). Analisa SWOT dan STP (Segmentasi, Tertarget, Posisi) Terhadap Strategi Pemasaran Digital Pada Usaha Mikro - Bunda Culinary. JKBM (Jurnal Konsep Bisnis dan Manajemen). 7 (2): 127-138 
Hendrawan, H. (2021). Analisa SWOT dan STP (Segmentasi, Tertarget, Posisi) Terhadap Strategi Pemasaran Digital ...

\section{PENDAHULUAN}

Tahun 2016, Google dan Temasek (Market Profiles - Data and Profiles / HKTDC Research, n.d.) melaporkan tentang penggunaan internet di negara-negara ASEAN dan Indonesia menempati urutan pertama dengan pengguna sebesar 215 juta. Riset terbaru Google dan Temasek dalam laporan e-Conomy SEA 2018 menunjukkan bahwa ekonomi digital Indonesia tahun ini mencapai US\$ 27 milyar (Nilai Ekonomi Digital Indonesia Tembus US\$27 Miliar, n.d.). Ini artinya Indonesia memegang urutan pertama dan berkontribusi sebesar 49\% di Asia Tenggara. Hanya saja berdasarkan survei tersebut juga, ternyata produk-produk dari Indonesia masih sedikit yang dijual di platform e-commerce yakni sebesar $10 \%$ saja.

Sementara itu berdasarkan survei yang dilakukan oleh Asosiasi Penyelenggara Jasa Internet Indonesia (APJII), bahwa pengguna internet pada tahun 2018 adalah sebesar 171,1 juta (Buletin APJII Edisi Mar 2018, 2018). Kontribusi pengguna per wilayah masih didominasi dari Jawa 55\%. Lalu disusul Sumatera 21\%, Sulawesi-Maluku-Papua 10\%, Kalimantan 9\%, dan Bali-Nusa Tenggara 5\%. Dalam survei tersebut juga dipaparkan bahwa Jawa Barat pemegang penetrasi internet tertinggi sebesar $16,6 \%$.

Dari data survei, produk-produk Indonesia masih terbuka lebar untuk dapat mempenetrasi pasar yang ada. Penetrasi ini membutuhkan suatu strategi tersendiri. Tak terkecuali pada dunia usaha sektor mikro. Dunia usaha di sektor mikro harus mengikuti perkembangan jaman yakni dengan mendisain ulang pola pemasarannya. Bila tidak mendisain pola pemasarannya maka bisnisnya terancam stagnan atau mandek atau malah gulung tikar.

Apalagi pola pemasaran dewasa ini adalah pemasaran digital. Dalam pemasaran digital sangat dibutuhkan suatu strategi yang handal dan tepat sasaran. Karena dalam pemasaran digital ini pertemuan antara pelaku usaha baik pembeli maupun penjual lebih banyak bertemu dalam dunia maya. Dengan demikian tingkat kepercayaan akan produk yang ditawarkan akan sangat dibutuhkan. Belum lagi tingkat persaingan usaha yang semakin samar dan bias. Karena masing-masing pelaku usaha berusaha untuk memasarkan produknya.

Berbagai macam teknik yang digunakan dalam menentukan strategi pemasaran digital agar bisa menentukan pemasaran yang tepat yang sesuai dengan tujuan perusahaan (Chaffey, 2017). Teknik yang digunakan dalam penelitian ini yang diambil oleh peneliti adalah teknik analisa SWOT dan STP. Dengan kedua analisa tersebut, peneliti ingin mengetahui strategi pemasaran digital yang sekiranya cocok untuk Bunda Culinary, Bogor. Penelitian yang bertempat di Bunda Culinary, Bogor karena jenis usaha ini adalah usaha mikro yang bergerak di bidang kuliner. Dan tujuan dari penelitian ini adalah untuk mengetahui strategi apa yang digunakan dalam pemasaran digital. Dari paparan di atas, maka peneliti ingin meneliti tentang Analisa SWOT dan STP terhadap Strategi Pemasaran Digital pada Bunda Culinary, Bogor.

Pengertian analisa SWOT yang dikemukakan oleh Freddy Rangkuti (2010) adalah identifykasi berbagai faktor yang secara sistematis untuk 
merumuskan strategi perusahaan. Analisa ini didasarkan pada logika yang dapat memaksimalkan kekuatan (strength) dan peluang (opportunities), tapi di sisi lain dapat meminimalkan kelemahan (weaknesses) dan ancaman (threats) (Novianto, 2019). Sementara itu Philip Kotler mengemukakan bahwa analisis SWOT adalah evaluasi terhadap semua kekuatan, kelemahan, peluang dan ancaman yang terdapat pada individu atau bisnis ataupun organisasi (Valentin, 2001). Lain halnya Pearce and Robinson berpendapat bahwa analisis SWOT adalah bagian dari proses manajemen stratejik perusahaan yang bertujuan mengidentifikas kekuatan, kelemahan, peluang dan ancaman (Mustofa, 2018). Dari ke empat elemen ini diper-gunakan untuk menghasilkan berbagai alternatif strategi.

Kelebihan dari analisa SWOT ini sangat bermanfaat di dalam mengidentifikasi permasalahan yang ada dalam diri pribadi/bisnis/organisasi sehingga dapat menggambarkan kondisi suatu perusahaan. Tapi analisa SWOT ini juga memiliki kelemahan. Di mana analisa SWOT ini bukanlah suatu alat yang dapat memberikan jalan keluar dari masalah perusahaan.

Analisa SWOT ini bila digambarkan ke dalam matriks maka akan tergambar sebagai berikut:

\begin{tabular}{|c|c|c|}
\hline IFAS & $\begin{array}{l}\text { Kekuatan } \\
\text { (Strength) }\end{array}$ & $\begin{array}{l}\text { Kelemahan } \\
\text { (Weakness) }\end{array}$ \\
\hline $\begin{array}{c}\text { Kesempatan } \\
\text { (Opportunity) }\end{array}$ & Strategi SO & Strategi WO \\
\hline $\begin{array}{l}\text { Ancaman } \\
\text { (Threat) }\end{array}$ & Strategi ST & Strategi WT \\
\hline
\end{tabular}

Dari gambar matriks di atas maka untuk disusun strategi yang berguna untuk menggambarkan kondisi usaha (bisnis). Adapun strategi tersebut sebagai berikut (Puspita Sari et al., 2017):

1. Strategi SO, Strategi ini dibuat dalam rangka memanfaatkan semua kekuatan yang ada dan peluang yang terbuka untuk peningkatan usaha (bisnis)

2. Strategi WO, Pada strategi ini dibuat dengan meminimalkan kelemahan yang ada tapi tetap memanfaatkan peluang yang ada untuk kemajuan usaha (bisnis)

3. Strategi ST, Pada bagian ini strategi yang perlu dikembangkan adalah pemanfaatan atas kekuatan yang dimiliki tapi juga harus bisa mengendalikan ancaman yang timbul dari luar lingkungan.

4. Strategi WT, Di bagian ini adalah bagian yang memakai strategi yang paling lemah dengan segala kelemahan dan ancaman yang ada.

\section{Analisa STP}

Penentuan posisi bisnis apalagi produk tentunya diperlukan beberapa analisa, diantaranya adalah analisa STP (Segmentation, Targeting, and Positioning). Analisa ini dipergunakan dalam rangka pemetaan usaha (bisnis) ataupun produk sehingga diharapkan tidak salah sasaran dalam penjualan atau peningkatan bisnis.

\section{Segmentasi (Segmentation)}

Fandy Tjiptono dan Gregorius Chandra mengemukan bahwa segmentasi dapat diartikan sebagai proses pengelompokkan pasar yang keseluruhan (heterogen) menjadi kelompokkelompok atau segmen tertentu (Safitra H, 2017). Kelompok atau segmen yang memiliki kesamaan dalam hal kebutuhan, keinginan, perilaku dan respon yang memerlukan pemasaran bauran tersendiri (Nurhadi, 2019). Apalagi dewasa ini di 
Hendrawan, H. (2021). Analisa SWOT dan STP (Segmentasi, Tertarget, Posisi) Terhadap Strategi Pemasaran Digital ...

mana era customer-oriented, dalam persaingan sangat ketat, pelanggan yang lebih berpengetahuan dan berpendidikan, dan permintaan yang terus berubah, mendesak perusahaan untuk memperhatikan masalah segmentasi (Clow \& Baack, 2009).

Segmentasi merupakan tahapan yang penting bagi sebuah usaha bisnis dapat menentukan kira-kira pasar yang akan menjadi target pasarnya. Segmentasi ini adalah memilah dan mengelompokkan berbagai pelanggan sesuai dengan karakteristik, kebutuhan, tuntutan dan lain sebagainya yang tentunya sesuai dengan tujuan perusahaan tersebut. Hal berikut yang dapat dijadikan pertimbangan dalam menentukan segmentasi, yaitu (Kotler \& Keller, 2016):

\section{Geografis.}

Beberapa contoh variabel geografis yang dapat digunakan untuk segmentasi, yakni: a) Wilayah: propinsi, kabupaten, kecamatan atau lingkungan; b) Ukuran area: elite, urban, kumuh, metropolitan, pinggiran, atau pedesaan; c) Kepadatan Penduduk: padat penduduk, perumahan, atau kampung; d) Iklim: dingin, tropis, sub-tropis.

\section{Demografis.}

Variabel segmentasi demografis meliputi: usia, gender, ukuran keluarga, siklus hidup keluarga, penghasilan, pekerjaan, pendidikan, generasi, etnisitas, kebangsaan, agama, kelas sosial, dan lain sebagainya.

\section{Psikografis}

Dalam segmentasi psikografis meliputi: minat, kegiatan, opini, nilai, sikap dan lain-lain.

\section{Tingkah laku}

Untuk segmentasi perilaku ini didasarkan pada perilaku pelanggan yang aktual terhadap produk, di mana meliputi: manfaat yang dicari, tingkat penggunaan, loyalitas merek, status pengguna, kesiapan untuk membeli dan kesempatan.

OC Ferrell dan Michael D Hartline dalam bukunya "Marketing Strategy" mengemukakan bahwa kriteria segmentasi pasar efektif adalah (Ferrel \& Hartline, 2011):

1. Terukur: Ukuran, daya beli dan karakteristik segmen dapat diukur.

2. Substansial: Segmen yang cukup besar serta menguntungkan untuk dilayani. Sebuah segmen harus menjadi kelompok homogen yang besar yang layak untuk dikejar dengan program pemasaran yang disesuaikan.

3. Dapat diakses: Segmen bisa dijangkau dan dapat dilayani secara efeketif.

4. Dapat di diferensial: Differentiable berarti segmen tersebut dapat dibedakan secara konseptual dan mempunyai respon yang berbeda terhadap elemen dan bauran pemasaran yang berbeda.

5. Dapat ditindak-lanjuti: Program yang efektif dapat diformulasikan untuk menarik dan melayani segmen.

\section{Tertarget (Targeting)}

Penentuan tertarget (Targeting) harus dirunut dari data segmentasi yang didapat (Sahir et al., 2021). Pemilihan segmentasi akan menentukan (1) beda cara pengukuran dan aksesbilitas ukuran; (2) cara penargetan yang terpisah; (3) jangkauan media komunikasi dan saluran pemasaran.

Permasalahan dari tertarget ini adalah bagaimana memilih, menyeleksi, dan dapat men- 
jangkau pasar. Karena sasaran dari dari suatu produk adalah pasar yang dibidik sesuai dengan kegiatan pemasaran (Kotler et al., 2017). Untuk itu ada beberapa jenis strategi target pasar, di antaranya:

1. Undifferentiated marketing atau mass marketing

Penggunaan strategi ini, perusahaan memutuskan untuk abai perbedaan segmen pasar serta memenuhi keseluruhan pasar dengan satu penawaran. Maksudnya, strategi harus lebih fokus kepada kebutuhan konsumen yang spesifik daripada yang lain.

\section{Differentiated marketing}

Pada strategi ini, perusahaan menargetkan beberapa segmen pasar dan mendesain penawaran yang terpisah kepada setiap segmen pasar. Dengan menawarkan berbagai variasi produk dan pemasaran ke dalam segmen, perusahaan berharap akan mendapatkan penjualan yang lebih tinggi dan mempunyai posisi yang kuat dalam setiap segmen.

\section{Concentrated marketing}

Dalam strategi ini difokuskan untuk memasarkan produk pada satu atau beberapa segmen/kelompok pembeli tertentu, sehingga pemasaran produk hanya ditujukan kepada kelompok pembeli yang sangat berpotensi. Dengan fokus pada segmen tertentu, perusahaan berusaha memberikan produk yang terbaik bagi pangsa pasar mereka. Perusahaan akan lebih hemat biaya baik produksi, distribusi, maupun promosi. Sebab semuanya fokus pada satu atau dua kelompok saja.

\section{Micromarketing}

Dalam strategi ini perusahaan akan menghasilkan produk yang disesuaikan dengan spesifik individu (individual marketing) dan lokasi tertentu (local marketing)

\section{Posisi (Positioning)}

Langkah terakhir dari analisa STP ini adalah penentuan posisi (Positioning) (Widjaya, 2017). Penentuan posisi ini dilakukan untuk mengukur produk atau brand kita berada di area mana (Durianto et al., 2004). Apakah sesuai dengan target yang kita inginkan. Untuk itu diperlukan langkah-langkah sebagai berikut:

1. Mengidentifikasi beberapa kumpulan keunggulan kompetitif yang berbeda. Kumpulan ini digunakan untuk membangun posisi.

2. Memilih keunggulan kompetitif yang tepat.

3. Dan memilih strategi positioning secara keseluruhan.

\section{Strategy Digital Marketing}

Industri 4.0 yang tengah bergulir dewasa ini secara langsung dan tidak langsung telah mengubah pola berbisnis. Perubahan pola berbisnis juga mengubah pola manajemen tak terkecuali pemasaran. Pola pemasaran dewasa ini haruslah berpola pemasaran digital atau Digital Marketing (Wardhana, 2015). Adapun pengertian Pemasaran Digital adalah penggunaan internet dan teknologi yang interaktif untuk membuat dan menghubungkan dialog antara perusahaan dan konsumen yang telah teridentifikasi. (Coviello et al., 2001). Sedangkan Ridwan Sanjaya dan Josua Tarigan mengemukakan bahwa Digital Marketing adalah kegiatan marketing termasuk branding yang menggunakan berbagai media berbasis web seperti blog, web site, e-mail, adwords, ataupun jejaring sosial. (Sandjaya \& Tarigan, 2009). 
Hendrawan, H. (2021). Analisa SWOT dan STP (Segmentasi, Tertarget, Posisi) Terhadap Strategi Pemasaran Digital ...

Berdasarkan pengertian di atas pemasaran digital menggunakan media yang berbasis web, maka sangat diperlukan sekali suatu strategi agar target pemasaran tercapai. Dan sebelum ber-bicara tentang strategi pemasaran digital, perlu diketahui bahwa pemasaran digital mempunyai beberapa karakteristik (Kingsnorth, 2016), yakni: 1. Pemasaran digital adalah upaya meningkatkan interaksi bisnis dengan pelanggan yang bergantung pada teknologi.

2. Sebuah dialog elektronik (teknologi interaktif) untuk memberikan akses informasi pada pelanggan (individu atau komunitas), begitu pula sebaliknya.

3. Pemasaran digital juga upaya untuk melakukan semua kegiatan bisnis melalui internet baik untuk penelitian, analisa bisnis hingga mempertahankan loyalitas pelangan.

4. Pemasaran digital juga meningkatkan percepatan jual beli barang atau jasa, informasi serta ide melalui jaringan internet.

Seperti dikutip dari laman cultbrandingcom terdapat 52 tipe strategi pemasaran yang biasa digunakan saat ini (52 Types of Marketing Strategies, n.d.). Akan tetapi dalam hal ini tidak semua dipaparkan di sini. Beberapa kanal marketing yang umumnya dipergunakan di antaranya adalah: (a) Relationship Marketing (Wahyono, 2013); (b) Transactional Marketing; (c) Word of Mouth Marketing (Word of Mouth Marketing, n.d.); (d) Seasonal Marketing (Seasonal Marketing: How to Apply It to Your Business / Unamo Blog, n.d.); (e) Online Marketing; (f) Social Media Marketing; (g) B2C Marketing; (h) Personalized Marketing (Veritrans, n.d.); (i) $\mathrm{Hu}$ manistic Marketing.
Tentunya semua saluran pemasaran di atas tidak semua dipergunakan. Hal ini akan disesuaikan dengan kebutuhan yang ada sesuai dari beberapa analisa di antaranya analisa SWOT dan analisa STP.

Dalam membangun strategi marketing digital, maka hal yang perlu disiapkan adalah mengetahui seberapa besar kekuatan internal dan kekuatan eksternal. Lewat analisa SWOT dimana dalam analisa ini terbagi atas kekuatan internal (IFAS) dan kekuatan eksternal (EFAS) (Trishartanto et al., 2018). Dari IFAS dan EFAS ini akan ditentukan jenis kanal marketing digital apa yang digunakan.

Tidak hanya dengan analisa SWOT saja, membangun strategi marketing digital diperlukan juga STP (Segmentation, Targeting, Positioning). Penggunaan STP ini diharapkan pemilihan kanal pemasaran digital akan semakin tepat. Pangsa pasar yang tepat tentunya akan mengurangi resiko kerugian yang lebih besar terutama biaya marketing.

\section{METODE PENELITIAN}

Metode penelitian yang digunakan dalam penelitian ini adalah survei deskriptif (Sugiyono, 2015). Jenis penelitian ini adalah studi kasus . Fokus dan lokus dari penelitian ini adalah menggali strategi pemasaran digital yang digunakan oleh "Bunda Culinary" melalui analisa SWOT dan analisa STP pada usaha mikro. Sehingga teknik analisanyapun menggunakan teknik analisa SWOT dan analisa STP. Dan teknik pengumpulan data yang digunakan adalah observasi, dan wawan-cara (Raco, 2010). Pada teknik analisa SWOT ini menggunakan pendekatan internal yak- 
ni Kekuatan (Strength) dan Kelemahan (Weakness) dan pendekatan eksternal yakni Kesempatan (Opportunity) dan Ancaman (Threats). Sedangkan untuk teknik analisa STP-nya menggunakan teknis analisis deskripsi.

\section{HASIL DAN PEMBAHASAN}

Bunda Culinary adalah usaha rumahan yang bergerak di bidang kuliner. Produk yang dijual beraneka ragam, yaitu kue kering, bolu/cake, rangginang, kacang oven dan lainnya. Akan tetapi yang menjadi objek penelitian dalam hal ini adalah produk kue kering saja. Hal ini dikarenakan produk ini merupakan andalan dan sudah dijalankan lebih dari 7 tahun.
Setelah dilakukan pengumpulan data-data untuk penelitian, maka didapat analisa sebagai berikut:

Bunda Culinary mempunyai kekuatan internal (IFAS) yang baik. Hal ini tergambar dari kekuatan (strength) yang dimiliki oleh Bunda Culinary yang mempunyai pangsa pasar tertentu karena yang dijual adalah panganan kering dengan kualitas tertentu dengan bobot 0,132 . Nilai yang sesuai dengan pangsa pasar tertentu tergambar dengan bobot 0,187 . Dan yang mendukung pemasarannya adalah adanya akun marketplace dan media sosial sebagai jembatan untuk marketing digital dengan bobot 0,105 . Akan tetapi terdapat kelemahan (weakness) yang sangat signifikan yakni kurangnya pemasaran aktif, bobotnya cukup besar yaitu 0.201 . Ini terlihat pada tabel berikut:

Tabel 1 Matrik Faktor Strategi Internal (IFAS)

\begin{tabular}{llrrr}
\hline No. & $\quad$ Faktor-faktor Strategi Internal & Bobot & Rating & $\begin{array}{c}\text { Bobot x } \\
\text { Rating }\end{array}$ \\
\hline & Strength (Kekuatan) & & & \\
\hline 1 & Punya pangsa pasar tertentu & 0,132 & 4,000 & 0,528 \\
\hline 2 & Cita rasa produk yang bagus & 0,093 & 4,000 & 0,372 \\
\hline 3 & Harga yang sesuai dengan pangsa pasar tertentu & 0,179 & 3,000 & 0,537 \\
\hline 4 & Menjual dan memproduksi produk kuliner jadul & 0,092 & 3,000 & 0,276 \\
\hline 5 & Mempunyai reseller di kota lain & 0,049 & 2,000 & 0,098 \\
\hline 6 & Mempunyai akun di marketplace dan medsos & 0,105 & 3,000 & 0,315 \\
\hline & $\quad$ & & & \\
\hline & Weakness (Kelemahan) & 0,201 & 3,000 & 0,603 \\
\hline 1 & Kurangnya pemasaran aktif & 0,043 & 2,000 & 0,086 \\
\hline 2 & Kemasan yang masih sederhana & 0,063 & 2,000 & 0,126 \\
\hline 3 & Kurangnya inovasi produk & 0,043 & 3,000 & 0,129 \\
\hline 4 & Masih dikerjakan sendiri & & & \\
\hline & & $\mathbf{1 , 0 0 0}$ & & $\mathbf{3 , 0 7 0}$ \\
\hline
\end{tabular}

Sumber: Hasil olah data tahun 2019

Adapun untuk kekuatan eksternalnya lain adalah tidak semua penjual yang kue kering (EFAS), Bunda Culinary juga tergambar dengan tradisional yang garap pangsa pasar tertentu. Ini baik. Untuk kekuatan kesempatan (opportunity) pangsa pasar kuliner terus berkembang sesuai dengan bobotnya yakni 0,295. Kesempatan yang sesuai dengan bobot 0,123 . Akan tetapi, yang menjadi ancaman (threat) dari luar yang tak kalah penting adalah persaingan yang ketat untuk 
Hendrawan, H. (2021). Analisa SWOT dan STP (Segmentasi, Tertarget, Posisi) Terhadap Strategi Pemasaran Digital ...

produk yang sejenis. Ini sesuai dengan bobotnya sesuai dengan bobotnya sebesar 0,093. Hal ini sebesar 0,164. Di sisi lain belum adanya admin seperti tergambar pada tabel berikut ini. khusus yang mengelola pemasaran digital. Ini

Tabel 2 Matrik Faktor Strategi Eksternal (EFAS)

\begin{tabular}{|c|c|c|c|c|}
\hline No. & Faktor-faktor Strategi Eksternal & Bobot & Rating & $\begin{array}{l}\text { Bobot } x \\
\text { Rating }\end{array}$ \\
\hline & \multicolumn{4}{|l|}{ Opportunity (Peluang) } \\
\hline 1 & Pangsa pasar kuliner yang terus berkembang & 0,295 & $4, .000$ & 1,180 \\
\hline 2 & Penjual produk kuliner jadul yang semakin berkurang & 0,103 & 3,000 & 0,309 \\
\hline 3 & Kemudahan penjualan via daring yang terbuka lebar & 0,074 & 3,000 & 0,222 \\
\hline 4 & Produk kuliner jadul yang semakin diminati pasar & 0,084 & 4,000 & 0,336 \\
\hline \multirow[t]{2}{*}{5} & $\begin{array}{l}\text { Masuk dalam komunitas kuliner tingkat lokal maupun } \\
\text { nasional }\end{array}$ & 0,064 & 2,000 & 0,128 \\
\hline & \multicolumn{4}{|l|}{ Threat (Ancaman) } \\
\hline 1 & Adanya produk sejenis dengan persaingan yang ketat & 0,164 & 4,000 & 0,656 \\
\hline 2 & Aktifitas promosi kompetitor & 0,065 & 3,000 & 0,195 \\
\hline 3 & Belum adanya admin yang mengelola pemasaran digital & 0,093 & 3,000 & 0,279 \\
\hline 4 & Perubahan harga pasokan dan kebijakan di bidang kuliner & 0,058 & 1,000 & 0,058 \\
\hline & Total & 1,000 & & 3,363 \\
\hline
\end{tabular}

Sumber: Hasil olah data tahun 2019

Berdasarkan kedua tabel baik IFAS maupun EFAS, maka bila dipetakan ke dalam matriks berikut akan nampak seperti ini:

Tabel 3 Matriks Internal Eksternal - SWOT

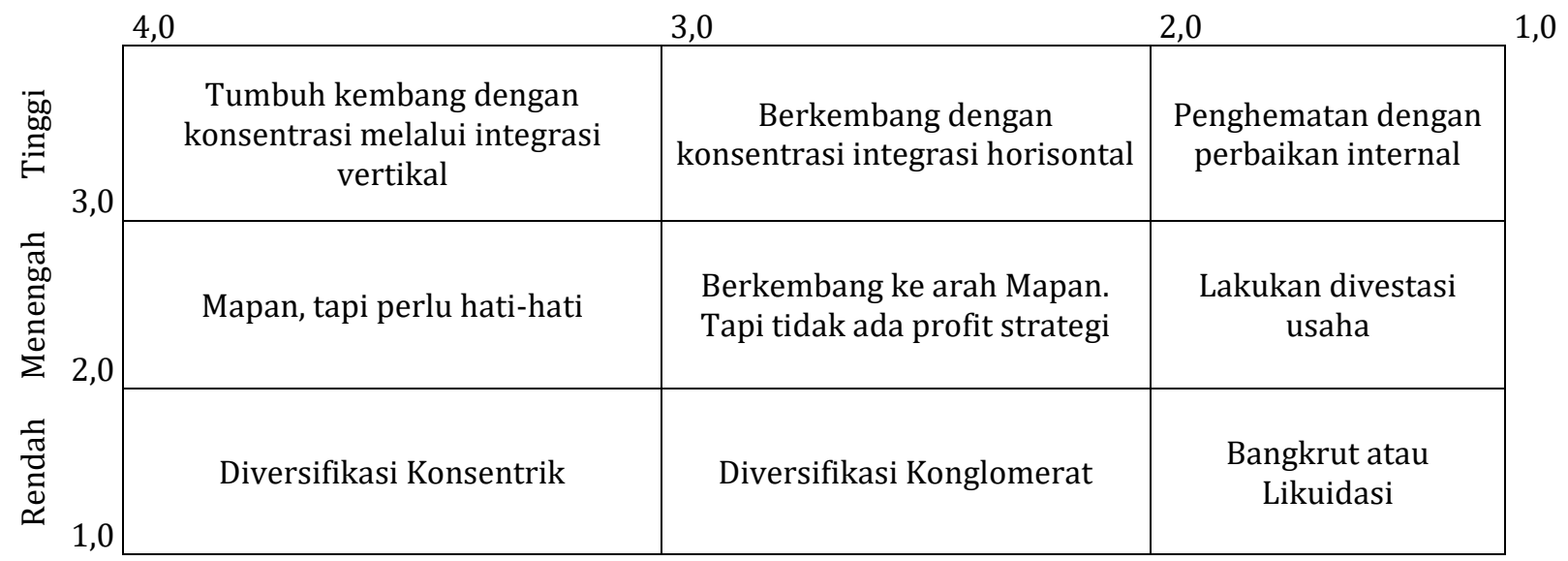

Dari tabel nampak bahwa Bunda Culinary berada dalam kuadran kiri atas yakni tumbuh kembang dengan konsentrasi melalui integrasi vertikal. Dan dilihat dari nilai dari matrik IFAS

Dengan demikian terkait dengan penerapan strategi marketing digital, maka Bunda Culinary mengambil langkah-langkah sebagai berikut: dan EFAS nya maka cenderung nilai EFAS lebih dominan dari IFAS. Sehingga faktor eksternal sedikit banyak mempengaruhi penerapan stra-tegi marketing digital.

1. Strategi SO

Penerapan untuk strategi SO ini, penerapannya dilakukan diantaranya adalah: 
a. Penguatan akan produk yang dipasarkannya dengan cara menjaga citarasa.

b. Memberikan harga yang kompetitif tanpa harus mengurangi citarasa atau takaran.

c. Memperluas jaringan pemasaran lewat reseller atau dropshipper.

d. Optimalisasi pemasaran lewat komunitas dan pertemanan.

2. Strategi WO

Untuk penerapan strategi WO ini, dilakukan beberapa kiat di antaranya adalah:

a. Inovasi produk dilakukan dengan menambah varian rasa.

b. Untuk produksi masal, maka penambahan karyawan dilakukan.

c. Perubahan kemasanpun dilakukan untuk menambah nilai jual.

3. Strategi ST

Dalam strategi ST ini, penerapannya yang dilakukan adalah: a. Mempelajari produk kompetitor untuk bahan evaluasi produk sejenis.

b. Pembelian pasokan bahan baku sesuai dengan kemampuan beli.

4. Strategi WT

Dan untuk strategi WT ini, penerapan yang sudah dilakukan adalah:

a. Belum adanya penerapan yang signifikan untuk mengatasi kondisi ini.

b. Semua masih dilakukan secara mandiri.

Sementara itu untuk mengetahui kaitannya STP (Segmentation - Targeting - Positioning) dengan Strategi Pemasaran Digital dapat dilihat bahasan berikut ini:

\section{Segmentasi (Segmentation)}

Dari data yang didapat untuk tahapan segmentasi ini Bunda Culinary menempatkan data pemasarannya sebagai berikut:

Tabel 4 Segmentasi

\begin{tabular}{ll}
\hline \multicolumn{1}{c}{ Segmentasi } & \multicolumn{1}{c}{ Keterangan } \\
\hline Wilayah/Kota & $\begin{array}{l}\text { Jawa Barat (Bogor, Bekasi), DKI Jakarta (Jakarta Selatan), Jawa } \\
\text { Timur (Surabaya) }\end{array}$ \\
\hline Kepadatan & Perkotaan \\
\hline Iklim & Tropis \\
\hline Demografi usia & $6-11,12-17,18-34,35-49,50-64$ \\
\hline Ukuran Keluarga & $1-2,3-4,5+$ \\
\hline Status Keluarga & Sendiri, Menikah, Menikah dengan anak2, Orang tua \\
\hline Gender & Pria, Wanita \\
\hline Pendapatan & IDR 2,500K - 5,000K \\
\hline Pekerjaan & Profesional; pekerja; pensiunan; siswa/mahasiswa; ibu rumah \\
& tangga; \\
\hline Pendidikan & SD, SMP, SMU, PT, \\
\hline Agama & Semua agama \\
\hline Ras & Jawa, Sunda, Batak, Melayu, \\
\hline Generasi & Gen X (Orang tua sekarang), Milenial (Gen Y) \\
\hline Kelas Sosial & Menengah ke atas \\
\hline Gaya Hidup & Kekeluargaan \\
\hline Suasana (Kondisi) & Spesial moment (Lebaran, Natal, Imlek) \\
\hline Kelebihan yang diberi & Kualitas, Rasa, Pelayanan \\
\hline Status pembeli & Pembeli loyal, pembeli baru, potensial pembeli \\
\hline Tingkat Penggunaan & Menengah \\
\hline
\end{tabular}


Hendrawan, H. (2021). Analisa SWOT dan STP (Segmentasi, Tertarget, Posisi) Terhadap Strategi Pemasaran Digital ...

\begin{tabular}{ll}
\hline \multicolumn{1}{c}{ Segmentasi } & \multicolumn{1}{c}{ Keterangan } \\
\hline Loyalitas & Menengah \\
\hline Tahapan siap beli & Berminat, Berkeinginan, Sadar \\
\hline Sikap terhadap produk & Antusias \\
\hline
\end{tabular}

\section{Penargetan (Targeting)}

Dari segmentasi yang terdata, maka penargetan yang diinginkan adalah sebagai berikut:

a. Area Pemasaran: Perkotaan (Bogor, Jakarta, Bekasi, dan Surabaya).

b. Karakteristik Pembeli: Keluarga/ Perorangan, dengan pendapatan minimum $\mathrm{Rp}$ $2.500 .000,0$

c. Tingkat sosial: Menengah ke atas.

d. Kondisi: Suasana lebaran, natal, imlek.

e. Calon Pembeli: Pembeli loyal dan royal,

\section{Memposisikan (Positioning)}

Tahapan terakhir dari STP ini adalah memposisikan. Maka Bunda Culinary khususnya produk kue keringnya dijual untuk kalangan tertentu yang tingkat sosialnya adalah menengah ke atas. Di mana pola pembeliannya adalah pola loyal dan royal. Karena pembeli sudah mengetahui kualitas dan citra rasa produk yang dibelinya. Sehingga untuk masalah harga bukan menjadi bahan pertimbangan yang utama.

Kaitannya STP dengan Strategi Pemasaran yang dipakai selama ini adalah penekanan pada kualitas produk dan pelayanan. Karena pada masyarakat dengan kelas sosial menengah ke atas, yang menjadi ekspektasi dari produk adalah kualitas produk dan pelayanan.

Dari penggunaan analisa SWOT dan STP pada Bunda Culinary dalam rangka Strategi Pemasaran Digital, maka Bunda Culinary menggunakan beberapa kanal pemasaran. Pemilihan kanal-kanal pemasaran ini disesuaikan dengan kebutuhan usaha. Dan kanal-kanal tersebut adalah Relationship Marketing, Word of Mouth Marketing, Seasonal Marketing, dan Social Media Marketing.

Pemilihan kanal Relationship Marketing karena Bunda Culinary masih menggunakan kekuatan pemasaran lewat komunitas seperti arisan ibu-ibu, pengajian ibu-ibu. Word of Mouth Marketing digunakan karena testimoni para pelanggan sangat menentukan rekomendasi tentang brand awareness. Seasonal Marketing dipakai karena memang pola pemasarannya hanya pada waktu tertentu saja. Social Media Marketing digunakan karena dominasi para pelanggan lebih mudah menggunakan media sosial seperti WA dan IG.

\section{SIMPULAN}

Dari bahasan di atas, maka dapat diambil simpulan bahwa lewat analisis yang dilakukan baik memakai analisa SWOT maupun analisa STP didapat bahwa produk Bunda Culinary yang dipasarkan mempunyai citarasa yang bagus dengan harga yang juga kompetitif untuk pangsa pasar yang diambil kelas menengah ke atas; dalam penanganan operasionalnyapun baik untuk produksi maupun pemasaran masih dilakukan secara mandiri dalam artian ditangani oleh pemilik usaha; dan untuk strategi untuk pemasaran digital yang dilakukan masih sekedar asalasalan. Hal ini tergambar dari pola yang dipakai yakni Relationship Marketing, Word of Mouth 
Marketing, Seasonal Marketing, dan Social Media

Marketing. Sementara untuk pengem-bangan ke arah B2B Marketing dan B2C Marketing belum tergarap dengan baik.

\section{DAFTAR PUSTAKA}

52 Types of Marketing Strategies. (n.d.). Retrieved November 16, 2020, from https://cultbranding.com/ceo/52-types-ofmarketing-strategies/

Anjelisa, Mananeke, L., \& Rogi, M. (2018). Analisis Pengaruh Strategi Segmentasi, Targeting dan Positioning (STP) terhadap Keputusan Pembelian Produk BP-Smart Protection di AJB BUMIPUTERA 1912 cabang Sam Ratulangi Manado. Jurnal EMBA, 6(4), 4073-4082. https://ejournal.unsrat.ac.id/index.php/emba/ article/viewFile/21970/21671

Buletin APJII Edisi Mar 2018. (2018). APJII. https://apjii.or.id/downfile/file/BULETINAPJII EDISI22Maret2018.pdf

Chaffey, D. P. S. (2017). Digital Marketing Excellence: Planning, Optimizing and Integrating Online ... Dave Chaffey, PR Smith - Google Books. Taylor \& Francis.

https://books.google.co.id/books?hl=en\&lr=\&id =biwlDwAAQBAJ\&oi=fnd\&pg=PP1\&dq=Various +kinds+of+techniques+are+used+in+determini ng+digital+marketing+strategies+in+order+to+ determine+the+right+marketing+in+accordanc $\mathrm{e}+$ with+company+goals\&ots $=$ CKvkTzllte\&sig $=\mathrm{H}$ $\mathrm{cHg}$

Clow, K. E., \& Baack, D. (2009). Marketing Management: A Customer-Oriented Approach. SAGE Publications. https://books.google.co.id/books?id=_PDfCQAA QBAJ

Coviello, N., Milley, R., \& Marcolin, B. (2001). Understanding IT-enabled interactivity in contemporary marketing. Journal of Interactive Marketing, $\quad 15(4), \quad 18-33$. https://doi.org/https://doi.org/10.1002/dir.10 20

Durianto, D., Sugiarto, \& Budiman, L. J. (2004). Brand Equity Ten Strategi Memimpin Pasar - Google Books. Gramedia Pustaka Utama. https://books.google.co.id/books?hl=en\&lr=\&id $=$ S4MDGeY68EYC\&oi=fnd \&pg=PP9\&dq=Penent uan+posisi+ini+dilakukan+untuk+mengukur+p roduk+atau+brand+kita+berada+di+area+mana \&ots=fWfWt2ISEg\&sig=JfOIrDoOLmxVpOGU5PDXhGSHJg\&redir_esc $=y \# v=$ onepage\& $q=P e n e n t u$ an posisi in

Ferrel, O. ., \& Hartline, M. D. (2011). Marketing Strategy. Cengage Learning.

Kalpande, S. D., Gupta, R. C., \& Dandekar, M. D. (2010). A SWOT analysis of small and medium scale enterprises implementing total quality management. Social Sciences, 1(1), 59-64.

Kingsnorth, S. (2016). Digital Marketing Strategy. Kogan Page Limited. https://books.google.co.id/books/about/Digital _Marketing_Strategy.html?id=eQDswEACAAJ\&redir_esc $=y$

Kotler, P., Kartajaya, H., \& Setiawan, I. (2017). Marketing 4.0. John Wiley \& Sons, Inc.

Kotler, P., \& Keller, K. L. (2016). Marketing Management (Global Edition) 13th Edition (Global Edi). Pearson Education Limited.

Market Profiles - Data and Profiles / HKTDC Research. (n.d.). Retrieved May 16, 2021, from https://research.hktdc.com/en/data-andprofiles/market-profiles

Mustofa, I. (2018). Analisis SWOT sebagai Dasar Strategi Pengadaan Bahan Baku Kayu Sengon Laut (Studi Pada UD. Duta Agung Jaya Purworejo Lumajang) [STIE Widya Gama Lumajang]. http://repository.stiewidyagamalumajang.ac.id /507/

Nilai ekonomi digital Indonesia tembus US\$27 miliar. (n.d.). Retrieved May 16, 2021, from https://www.indotelko.com/read/1542770317 /nilai-ekonomi-digital-indonesia

Noor, S. (2014). Penerapan Analisis Swot Dalam Menentukan Strategi Pemasaran Daihatsu Luxio Di Malang. Jurnal INTEKNA, 14(2), 102-209.

Novianto, K. (2019). Business Model Canvas - The Foundation Micro Apartment (Final Project). http://202.93.229.230/bitstream/handle/1234 56789/685/Krisna Novianto 2016213082019.pdf? sequence $=1 \&$ isAllowed $=\mathrm{y}$

Nurhadi, N. (2019). Manajemen Strategi Pemasaran Bauran (Marketing Mix) Perspektif Ekonomi Syariah. HUMAN FALAH: Jurnal Ekonomi Dan Bisnis Islam, 6(2), 141-157. http://jurnal.uinsu.ac.id/index.php/humanfalah /article/view/4811

Puspita Sari, D., Oktafianto, A., Soedarto, J., \& Undip Tembalang, K. (2017). Seminar Nasional IENACO-Penentuan Strategis Bisnis Menggunakan Analisis SWOT dan Matriks IFAS - EFAS pada CV. DINASTY. Penentuan Strategis Bisnis Menggunakan Analisis SWOT Dan Matriks IFAS - EFAS Pada CV. DINASTY, 238-245. https://publikasiilmiah.ums.ac.id/xmlui/bitstre am/handle/11617/8671/IENACO 042.pdf? sequence $=1$ \&isAllowed $=y$

Raco, J. (2010). Metode penelitian kualitatif: jenis, karakteristik dan keunggulannya. Grasindo.

Rangkuti, F. (2016). Teknik membedah kasus bisnis Analisis SWOT. KOmpas gramedia.

Safitra H, R. (2017). Analisis Pengaruh Strategi Segmenting, Targeting dan Positioning Terhadap Keputusan Pelanggan Membeli $\mathrm{Nu}$ Green Tea. Jurnal Ekonomika Dan Manajemen, 6(1), 28-44. https://journal.budiluhur.ac.id/index.php/ema 
Hendrawan, H. (2021). Analisa SWOT dan STP (Segmentasi, Tertarget, Posisi) Terhadap Strategi Pemasaran Digital ...

/article/view/336/280

Sahir, S. Hafni, Mardia, M., Nina, M., Hamidah, S. O., Dewi, I. K., \& Bonaraja, P. (2021). Dasar-Dasar Pemasaran. Yayasan Kita Menulis. https://books.google.co.id/books?id=MqUdEAA AQBAJ\&dq=Penentuan+targeting+syafrida\&lr= \&source=gbs_navlinks_s

Sandjaya, R., \& Tarigan, J. (2009). Creative Digital Marketing - Google Books. PT. Elek Media Komputindo.

https://books.google.co.id/books?hl=en\&lr=\&id =F9NBDwAAQBAJ\&oi=fnd\&pg=PP1\&dq=ridwan +sandjaya,+josua+tarigan\&ots=qtS1sbVRdc\&sig =7XY9o_ktDnELRr6HiyqjHIDT93I\&redir_esc=y \#v=onepage\&q=ridwan sandjaya\%2C josua tarigan $\& \mathrm{f}=$ false

Seasonal Marketing: How to Apply It to Your Business / Unamo Blog. (n.d.). Retrieved May 16, 2021, from https://unamo.com/blog/inboundmarketing/seasonal-marketing

Sugiyono. (2015). Metode Penelitian Kuantitatif, Kualitatif, dan RnD. Alfabeta.

Trishartanto, P., Warsa, M. M., \& Fathoni, A. (2018). Analisis EFAS-IFAS dikaitkan dengan Regulasi Industri Pengiriman via Airfreingt pada PT. Angkasa Pura Logistik cabang Semarang. Journal of Management, 4(4), 22. http://jurnal.unpand.ac.id/index.php/MS/articl e/view/1015

Valentin, E. K. (2001). Swot Analysis from a Resource-
Based View. Journal of Marketing Theory and Practice, 9(2), 54-69. https://doi.org/10.1080/10696679.2001.1150 1891

Veritrans. (n.d.). Alasan Personalized Marketing Penting untuk Bisnis Online Anda / Midtrans. Retrieved November 27, 2020, from https://midtrans.com/blog/alasanpersonalized-marketing-penting-untuk-bisnisonline-anda

Wahyono, B. (2013). Pengertian Relationship Marketing (Pemasaran Relasional) / Pendidikan Ekonomi.

http://www.pendidikanekonomi.com/2013/02 /pengertian-relationship-marketing.html

Wardhana, A. (2015). Strategi Digital Marketing dan Implikasinya Pada Keunggulan Bersaing UKM diI Indonesia.

https://www.researchgate.net/publication/327 069950

Widjaya, P. G. (2017). Analisis Segmenting Targeting Positioning dan Marketing Mix pada PT Murni Jaya. Agora, 5(1). http://publication.petra.ac.id/index.php/manaj emen-bisnis/article/view/5307

Word of mouth marketing. (n.d.). Retrieved May 16, 2021, from https://www.bigcommerce.com/blog/word-ofmouth-marketing/\#what-is-word-of-mouthmarketing 